\title{
PRODUÇÃO DA MEMÓRIA SOBRE A GUERRILHA DO ARAGUAIA NO DOCUMENTÁRIO "ARAGUAIA: CAMPO SAGRADO"
}

\author{
PRODUCCIÓN DE LA MEMORIA SOBRE LA GUERRILLA DEL ARAGUAYA \\ "DOCUMENTARIO" ARAGUAIA: CAMPO SAGRADO "
}

\section{PRODUCTION OF THE MEMORY OF THE GUERRILLA DEL ARAGUAYA "DOCUMENTARY" ARAGUAIA: SACRED FIELD "}

\section{Marcondes da Silveira Figueiredo Júnior ${ }^{1}$ Plábio Marcos Martins Desidérioº}

\begin{abstract}
Resumo: Este artigo procurou, a partir do filme "Araguaia: Campo Sagrado" (2011) realizar uma hermenêutica das narrativas dos atores sociais - camponeses - com o enfoque da produção da memória sobre a Guerrilha do Araguaia. Para elaboração da pesquisa, foi necessária a abordagem sobre a memória trabalhada por Le Goff (2011) e Pollak (1989) para que se tenha uma perspectiva sobre a memória coletiva produzida. Utilizando-se da hermenêutica proposta por Gadamer (1999) buscou compreender essas narrativas falas dos sujeitos presentes no filme, tentando entende-las inclusive na perspectiva contemporânea. Problematizou a opressão aos camponeses e guerrilheiros na região de Xambioá e povoados às margens do Rio Araguaia no Tocantins e no Pará, durante o confronto da Guerrilha do Araguaia. As memórias então produzidas são de medo, sofrimento e aversão ao regime instalado na época, bem como se depreende das falas dos sujeitos sociais entrevistados, que ainda traumas que foram vivenciados.
\end{abstract}

Palavras-chave: Araguaia - Campo Sagrado; Guerrilha do Araguaia; narrativas.

Abstract: From Araguaia: Campo Sagrado (2011), this article sought to carry out a hermeneutic of the narratives of the social actors - peasants - with the focus of the production of memory on the Araguaia Guerrilla. For the elaboration of the research, it was necessary to approach the memory worked by Le Goff (2011) and Pollak (1989) to have a perspective on the collective memory produced. Using the hermeneutics proposed by Gadamer (1999) sought to understand these narratives talks about the subjects present in the film, trying to understand them even in the contemporary perspective. He problematized the oppression of peasants and guerrillas in the region of Xambioá and settlements on the Araguaia River in Tocantins and Pará during the confrontation of the Araguaia Guerrilla. The memories then produced are fear, suffering and aversion to the regime installed at the time, as well as from the speeches of the social subjects interviewed, which are still traumas that have been experienced.

Keywords: Araguaia - Campo Sagrado; Guerrilla of the Araguaia; narratives.

\footnotetext{
${ }^{1}$ Mestre em Estudos de Cultura e Território pela Universidade Federal do Tocantins e Professor da Faculdade Católica D. Orione - Araguaína (TO). E-mail: marcondes@ catolicaorione.edu.br

2 Doutor em Comunicação. Professor do Programa de Pós-Graduação em Estudos de Cultura e Território e do Curso de História da UFT - Campus de Araguaína (TO). E-mail: plabio@uft.edu.br
} 
Resúmen: Este artículo buscó, a partir de la película "Araguaia: Campo Sagrado" (2011) realizar una hermenéutica de las narrativas de los actores sociales - campesinos - con el enfoque de la producción de la memoria sobre la Guerrilla del Araguaia. Para la elaboración de la investigación, fue necesario el abordaje sobre la memoria trabajada por Le Goff (2011) y Pollak (1989) para que se tenga una perspectiva sobre la memoria colectiva producida. En el caso de la hermenéutica propuesta por Gadamer (1999) buscó comprender estas narrativas de los sujetos presentes en la película, intentando entenderlas incluso en la perspectiva contemporánea. En el marco de la confrontación de la guerrilla del Araguaia, se planteó la opresión a los campesinos y guerrilleros en la región de Xambioá y poblados a orillas del río Araguaia en Tocantins y en Pará. Las memorias entonces producidas son de miedo, sufrimiento y aversión al régimen instalado en la época, así como se desprende de las palabras de los sujetos sociales entrevistados, que aún traumas que fueron vivenciados.

Palabras-clave: Araguaia-Campo Sagrado; Guerrilha del Araguaia, narrativas.

\section{Introdução}

No presente artigo se busca analisar a produção fílmica "Araguaia: Campo Sagrado", a partir da interpretação de algumas falas dos sujeitos sociais que vivenciaram a Guerrilha do Araguaia ocorrida no início da década de setenta, em pleno regime militar.

Ao escolher a presente temática, o interesse foi despertado pelo conteúdo da história oficial e a história retratada por aqueles que se encontram à margem do conteúdo dos livros de história que retratam o tema. A versão daqueles que viveram e participaram do confronto, na condição de camponeses, traz novos traços para a construção daquela história, permeada de dor, sofrimento e angustia.

Através da utilização da produção fílmica de gênero documentário, o estudo e a rememoração da história passa a ser mais atrativo e significativo, pois se tem a possibilidade de facilitar a formação de ideias sobre um determinado fato histórico.

O método que será utilizado é a hermenêutica, na perspectiva de Gadamer (1999), que propôs uma hermenêutica unitária, onde a busca pelo sentido se inicia nos estudos das percepções dos indivíduos, sendo que essas percepções vêm a se compor pelo somatório dos valores individuais, com a influência dos valores sociais, que serão esteio para toda a atividade de interpretação. Sendo então, realizada uma projeção de sentido, na qual será analisada pela ótica do processo de compreensão. Assim fazendo, nas falas dos camponeses e demais personagens que participaram ativamente daquele momento na história, se propõe analisar o contexto histórico da época para se ter um vislumbre dos sentidos então produzidos. 
Busca-se no presente trabalho responder quais as reminiscências que emergem das falas dos entrevistados no documentário "Araguaia: Campo Sagrado", em um processo de compreensão do que foi a guerrilha do Araguaia e qual a influência do idealizador daquela produção fílmica na produção dos sentidos. Assim, pode-se destacar que o problema de pesquisa então repousa na indagação de como a guerrilha do Araguaia e a própria administração do Estado pelos militares são vistos por aqueles que vivenciaram o regime enquanto observadores dos confrontos entre os agentes estatais e os opositores daquela administração, sem esquecer sua correlação com os elementos exógenos, bem como aqueles inerentes às intencionalidades de quem vem a produzir o documentário.

\section{Documentário e memória}

O cinema, visto como meio de expressão da arte, deve ser explorado também como forma de difusão de um discurso, contribuindo para a construção dos significados sociais. $\mathrm{O}$ encontro da arte de filmagem e montagem, bem como o processo de produção, resultam num conjunto de significados, que serão objeto de transmissão, para que os elementos som e imagem possam produzir sentidos.

Nichols (2005) destaca que não se pode dissociar por completo a ficção do documentário, pois várias técnicas são utilizadas tanto na ficção como no gênero documentário, como a própria roteirização, encenação, reconstituição, ensaio e interpretação. Assim, muito embora "Eles estão baseados em suposições diferentes sobre seus objetivos, envolvem um tipo de relação diferente entre o cineasta e seu tema e inspiram expectativas diversas no público" (NICHOLS, 2005, p. 17) não há uma ruptura completa entre ambos.

O mesmo autor ao abordar as questões das técnicas empreendidas na produção cinematográfica que tentam transmitir a realidade de determinado fato, alerta que toda a construção da película perpassa por um processo de industrialização para dar impressão de autenticidade (NICHOLS, 2005). Neste jogo de imagens selecionadas, dispostas em padrões ou sequências, a interpretação e o significado irão depender de outros fatores.

No cinema a imagem, em geral, é explorada em toda a sua densidade como forma de linguagem e significa sem vir ancorada no verbal. É usada como imagem que é, como forma de linguagem e não como cenário. Portanto, tem aí uma textualidade diferente da que se vê nos outros meios de comunicação. Diferente da imagem na TV, a qual pode boa parte do tempo ser apenas ouvida, a imagem no cinema compõe cada nó no tecido visual, não podendo ser descartada, como na TV (SOUZA, 2001). 
Neste contexto, se percebe que a densidade abordada pelo autor, trata-se de uma gama de significados que contém em uma imagem cinematográfica. Nichols (2005) ao abordar a temática sobre a abordagem conceitual diz que no documentário possui "conceito vago", até mesmo porque não adota um conjunto fixo de técnicas, possuindo características diversas.

Alerta o autor, também, sobre a existência de filme ficcional e não-ficcional, fazendo uma divisão de gêneros, como sendo os de "satisfação de desejos" e os de "representação social", assim, os primeiros seriam aqueles que versam sobre os sonhos e pesadelos, tornando visível e audível aquilo que era imaginável. Já os de "representação social" seriam os nãoficcionais, ou seja, representam aspectos de um mundo já compartilhado (NICHOLS, 2005).

No entendimento de Nichols (2005), o documentário adentra ao mundo como representação, fazendo isso ao oferecer um retrato condizente com o mundo que é conhecido ou conhecível, tornando uma base para a crença do real; ademais, os argumentos ou descrições nele inserido, torna possível ver o mundo de uma outra maneira, assim, há uma defesa de um determinado ponto de vista. Assim, há uma representação do mundo histórico e não necessariamente uma reprodução da realidade nos moldes de como ela ocorreu. A representação é produto do seu idealizador, sendo seu ponto de vista do passado.

[...] os documentários representam o mundo histórico ao moldar o registro fotográfico de algum aspecto do mundo de uma perspectiva ou de um ponto de vista diferente. Como representação, tornam-se uma voz entre muitas numa arena de debate e contestação social (NICHOLS, 2005, p. 73).

Como visto, não há como dissociar o idealizador da obra fílmica não-ficcional na construção das representações da verdade retratada ao final da película, devido as técnicas utilizadas que espelham seu pensamento. No entanto, mesmo com a presença de um roteiro, não há como prever o que os sujeitos sociais irão reproduzir durante a entrevista; mas não se pode colocar ao largo a possibilidade de edição, fazendo com que se reproduza tão somente as intencionalidades de seu idealizador. Ademais, na película não-ficcional, há uma tentativa de reprodução de uma realidade anteriormente vivenciada, ou ao menos, a representação dessa. Assim, embora sob a ótica daquele que o produz, há uma gama de fatores que se entrelaçam fazendo com que novas perspectivas sejam abordadas na temática não-ficcional, cujo roteiro já se tinha previamente disposto.

O documentário não-ficcional, como mencionado, vem trazer uma representação da verdade e não uma reprodução fiel dela. Alguns documentários foram realizados sobre a ditadura militar e a guerrilha do Araguaia. Um dos últimos "Soldado do Araguaia" (2018) de 
Belisário Franca, retrata a história na voz de um ex-militar do regime, trata-se do ex-cabo Elias; o cineasta focou em soldados de baixa patente e oriundos da própria região do Araguaia, onde as famílias destes militares sobreviviam no meio rural. $\mathrm{Na}$ época, tais aspirantes às Forças Armadas, tinham no Exército a ideia de um futuro diferente dos vivenciados por seus familiares.

A ditadura no país teve duração de mais de vinte anos, e é possível afirmar que esse foi um período de grande sofrimento e luta para os brasileiros. Vários governantes chegaram ao poder nesse período, cada um com a sua própria característica de comando e controle.

Vale lembrar, que a Guerrilha aconteceu ao norte do Estado do Tocantins. Os discursos sobre o embate e a atuação dos militares foram, na época, legados ao esquecimento, muitos torturados e vários guerrilheiros executados, porém tais episódios foram velados. As execuções presenciadas pela população, em sua grande maioria eram denominadas como sendo suicídios ou fugas, para que durante a vigência do esquecimento institucionalizado, se produzisse uma representação da verdade na elaboração da história oficial. Silva (2016, p. 03) aponta que durante a guerrilha do Araguaia "muitos moradores sofreram de perto com as prisões e torturas, sob a acusação de acobertarem os comunistas ou simpatizarem com seus ideais". A autora retrata sobre a mobilização dos guerrilheiros na região Norte do Brasil.

Xambioá não foi propriamente o foco de atuação dos guerrilheiros, concentrados em localidades no sul do Pará, mas serviu principalmente como base de apoio aos milhares de militares que se dirigiram para a região com o objetivo de combater os militantes do PCdo B envolvidos com a luta armada contra a ditadura militar (19641985).

Depreende-se que a questão geográfica abordada pela autora, vem a denotar a forma com a qual os guerrilheiros estavam se estabelecendo na região para se opor de forma mais organizada em face ao nefasto regime.

Silva (2016) ainda destaca a disparidade de armas e o consequente massacre engendrado pelo Governo que dizimou os guerrilheiros que se encontravam na região, no desiderato de silenciar os fatos.

Terminado o confronto pela aniquilação dos guerrilheiros resultante da acentuada assimetria de forças e intenção de não fazer prisioneiros, a estratégia do governo militar é a do silenciamento e do esquecimento: não se pode falar; não se deve lembrar a insurgência à ordem nascida nas regiões remotas do país (SILVA, 2016, p. 04). 
A autora destaca, de forma muito precisa, a disparidade de forças empreendidas no confronto, que fez com que, na realidade, se tornasse um verdadeiro palco sangrento, local em que os guerrilheiros foram dizimados pelos agentes do governo militar.

Ademais, vale lembrar que os sujeitos sociais neste confronto, não são apenas os guerrilheiros e os militares, também se deve ter atenção a importância dos moradores daquela região que recebeu o conflito armado, Medeiros vem fazer alusão a este ponto ao destacar que

\begin{abstract}
A maioria dos trabalhos sobre a Guerrilha do Araguaia investiga e publicita, basicamente, o conflito armado e a oposição entre guerrilheiros e militares, como se esses fossem os únicos sujeitos históricos desse processo. Nesse sentido, os moradores da região, suas expectativas, seus modos de viver e suas memórias são opacizadas na reconstrução do processo. (MEDEIROS, 2013, p. 258)
\end{abstract}

A invasão dos militares na região, se tornou marca indelével na paisagem local dos ribeirinhos. A permanência no local da ocorrência da guerrilha até a presente data, fez com que estes sujeitos sociais aguçassem suas lembranças quando do processo de reminiscência. As más experiências vividas durante o embate, fizeram com que os camponeses realizassem uma construção de um discurso agrupador.

O efeito advindo daquele regime em atuação durante a guerrilha, foi sentido também por diversas comunidades ribeirinhas, atingindo os camponeses e índios que ali viviam, transformando suas vidas e alterando sua forma de existência.

A partir do documentário "Araguaia: campo sagrado" serão abstraídas representações da realidade a partir da visão de diferentes atores sociais, com as influências e técnicas de filmagens utilizadas pelo produtor da película, fazendo um processo de recodificação do passado através de instâncias da memória.

No campo da memória, esta pode ser tratada como um arquivo daquilo que nos aparenta importante e marcante. Lembranças alocadas na memória podem sofrer o esquecimento, pela presença de contradições, lacunas, pela pouca importância de certas vivências etc. No entanto, vale ressaltar que quando um arquivo é pouco instigado, utilizado, vai se esvaindo com o passar do tempo.

Quanto a oscilação da memória e suas fragilidades, Silva destaca que

É do acontecimento e da memória que trata este texto e, por isso mesmo, dos movimentos do sujeito em busca do sentido para o vivido, prolongando seus efeitos pelas retomadas da reminiscência, enquanto acrescenta ressignificações. Nessa direção, tomamos como pressuposto de que a memória é sempre 'imperfeita', no sentido de sua incapacidade de comportar as 'agudezas' da experiência, mas é nela que se constrói a 'legibilidade' para o acontecimento, o que sobreveio, o momento 
fulgural para aquele que se inscreve a posteriori como sujeito da memória. (SILVA, 2016, p. 2)

Como visto, não se pode ter a memória construída a partir da noção de sua infalibilidade, pois as nuances do tempo denotam as imperfeições no processo de reconstrução do passado. No entanto, as reminiscências, faz com que se produzam ressignificações, sem se perder a pedra de toque do acontecimento que se tenta rememorar.

Ricouer (2007), trata sobre os rastros que levam à lembrança e suas modalidades, vem trazer, também, o apagamento e a persistência destes rastros; nota-se que quando são poucos os resquícios de lembrança, a tendência é que haja um esquecimento mais acelerado.

$\mathrm{Na}$ ditadura militar, sob a égide do autoritarismo, o controle do silêncio político foi permeado na sociedade, as únicas vozes ouvidas foram as da autoridade controladora, que detinha o poder da efetiva distribuição do conhecimento, isto é, transmitindo o que deveria ser propalado e o que necessitaria ser censurado.

Os livros tentam demonstrar em sua grande maioria a visão dos militantes, e acabam apenas reservando espaço para essas interpretações não levando em conta, talvez, a importância do questionamento das fontes independentes e se estas são de origem militante ou militar, ou seja, vencedores ou vencidos - se é que podemos usar tal termo ao falarmos do complexo período em que este trabalho se insere, o que poderia levar a interpretação de tais livros, sobretudo os trabalhados em torno de depoimentos de militantes, que são a grande maioria, a uma nova área de interpretação.

A esse respeito, ilustra Medeiros:

\begin{abstract}
Nossa proposta, entretanto, segue em outra direção. Embora reconheçamos a importância da ação dos Guerrilheiros que tombaram nas matas que circundavam os rios Araguaia e Tocantins, lutando pela redemocratização do país, consideramos que a história e a historiografia têm uma dívida para com os demais sujeitos que, num primeiro momento, de forma inesperada, tiveram que se envolver naquele processo, que, a priori, não lhes dizia respeito: os moradores da região na qual o conflito armado entre militares e guerrilheiros fora deflagrado. (MEDEIROS, 2013, p. 258)
\end{abstract}

Nesse contexto se percebe a preocupação do autor em fazer emergir a necessidade de trazer à discussão o papel daqueles atores, que embora não participaram ativamente do confronto, mas por serem moradores da região, sofreram os efeitos diretos da guerrilha do Araguaia. E neste cenário, ao dialogarmos com as forças empreendidas na região, temos um vislumbre coletivo daqueles personagens, uma memória dita coletiva daqueles eventos. 
Na medida em que há uma correlação entre poder e memória ao inferir a história, cada período analisado, sob a ótica desta relação, deve aderir a uma memória coletiva producente, para que a relação entre memória e história sirva de "libertação" para os homens.

A memória, onde cresce a história, que por sua vez a alimenta, procura salvar o passado para servir o presente e o futuro. Devemos trabalhar de forma a que a memória coletiva sirva para a libertação e não para a servidão dos homens (LE GOFF, 2011, p. 47).

Pretende-se com a análise do documentário "Araguaia - Campo Sagrado" compreender a memória dos camponeses sobre a guerrilha; o que será realizado a partir das narrativas e formas de representações, testando a possibilidade da ocorrência do esquecimento ou silenciamento nos sujeitos sociais. A partir da análise da memória produzida pelas falas dos personagens, dentre eles, de Seu Beca que é um dos atores sociais presentes na abertura e do encerramento desta produção fílmica dirigida por Evandro Medeiros, pretende-se alcançar o que de fato aqueles camponeses e demais personagens recordam do regime totalitário, precisamente da guerrilha do Araguaia.

Perceber-se-á que a narrativa advinda das relações de resistência faz surgir na rememorização destes sujeitos sociais, guerrilheiros e camponeses, a lembrança de aspectos cruéis do período e suas consequências, não somente consequências da verdade então silenciada que vigora em um regime autoritário, mas também emergem aspectos particulares que marcaram de forma indelével aqueles sujeitos. Vindo então, a servir de um desabafo e ao mesmo tempo um refrigério por dar visibilidade a estes ditos esquecidos, que foram silenciados pelo regime de exceção.

Para uma melhor clareza de sentidos, nas percepções dos indivíduos entrevistados na obra fílmica “Araguaia: Campo Sagrado", sendo que essas percepções vêm a se compor por um somatório dos valores individuais, com a influência dos valores sociais, que serão esteio para toda a atividade de interpretação, em um processo de compreensão, se utilizará a hermenêutica proposta por Gadamer (1989).

Para que haja um processo de compreensão mais produtivo, necessário um grau de interesse elevado, pois a interpretação dada pelo sujeito deriva da absorção de informações inferidas. Ademais, os nossos sentidos produzidos são frutos de uma interpretação arraigada de outras projeções e do nosso próprio modo de atribuição qualitativa advinda de nossas preconcepções. 
Pela necessidade da interpretação das falas dos sujeitos sociais a partir da investigação gadameriana, onde se busca um meio para compreensão do indivíduo no mundo, há o cuidado, como já retratado, de se observar os fatores exógenos que permeiam as falas para uma fidedigna percepção dos discursos empreendidos na produção fílmica.

Como mencionado, Gadamer (1999) identifica a necessidade de um processo interpretativo unitário, onde a interpretação e os elementos de aplicação fazem parte da construção do sentido, não havendo disciplinas interpretativas isoladas, devendo ser observados todos os fenômenos em um único processo hermenêutico, que embora de aparência multifacetada, as características múltiplas se tornam partes de um todo. Assim, nas representações sociais de determinados fatos históricos apresentados no documentário, há a necessidade de observância de outros elementos, que não somente a oralidade advinda dos sujeitos sociais. Neste ponto vale lembrar, que para Heidegger, filósofo no qual Gadamer (1999) baseou seus estudos, diz que o sentido vem do mundo, por intermédio das intencionalidades nas compreensões humanas.

Gadamer (1999) não se propõe a conhecer o passado à luz do presente, mas concede ao passado uma singularidade, onde a história deve produzir um conhecimento livre. O ponto alto da interpretação gadameriana é escapar do senso comum, das fórmulas preconcebidas, onde para a penetração dos sentidos, há constante renovação do ato interpretativo.

A partir das falas dos camponeses e demais personagens que participaram daquele momento na história, se propõe analisar o contexto histórico da época para se ter um vislumbre dos sentidos então produzidos.

Assim, vale destacar, que ao abordar o documentário como mola propulsora do presente estudo, há a necessidade de decupagem da obra, analisando cada cena, para que se possa inferir uma interpretação das falas dos sujeitos sociais, até pela motivação de haver a necessidade de descrição das falas para análise conjunta e possível confrontação entre os discursos daqueles atores culturais.

$\mathrm{Na}$ tentativa de demonstrar por meio do documentário a experiência dos atores sociais presentes na obra "Araguaia - Campo Sagrado", deve-se fragmentar as falas, na busca de interpretar as memórias armazenadas no tocante aos eventos ocorridos durante o regime militar.

Destarte, com o processo de decupagem da obra fílmica, em que será analisado a película em um processo de fragmentação dos sons e imagens, precisamente nas falas, com a necessária transcrição deste elemento sonoro, se retratará a construção da memória, precisamente a coletiva, a partir das representações da verdade. 


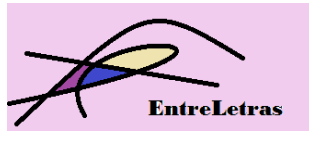

Por isso, o estudo da obra cinematográfica será realizado a partir da conjugação de diversos fatores inerentes à produção fílmica, para que se tenha um processo de interpretação que nos faça contextualizar uma representação daquele momento a partir das falas dos sujeitos sociais. Ademais, o estudo mediante esses fatores, nos trará as reminiscências produzidas do período ditatorial calcadas na perspectiva de seu idealizador.

Reportemo-nos, agora, ao estudo do documentário “Araguaia : Campo Sagrado”.

\section{Araguaia: "Campo Sagrado"}

Quanto ao objeto de pesquisa, trata-se da produção fílmica de gênero documentário denominado "Araguaia: Campo Sagrado"3. A película tem como a temática a Guerrilha do Araguaia, 1971, a partir das narrativas de camponeses que testemunharam ou participaram dos fatos, como presos e torturados pelo então regime de exceção.

Figura 01 - Imagem de Divulgação do documentário

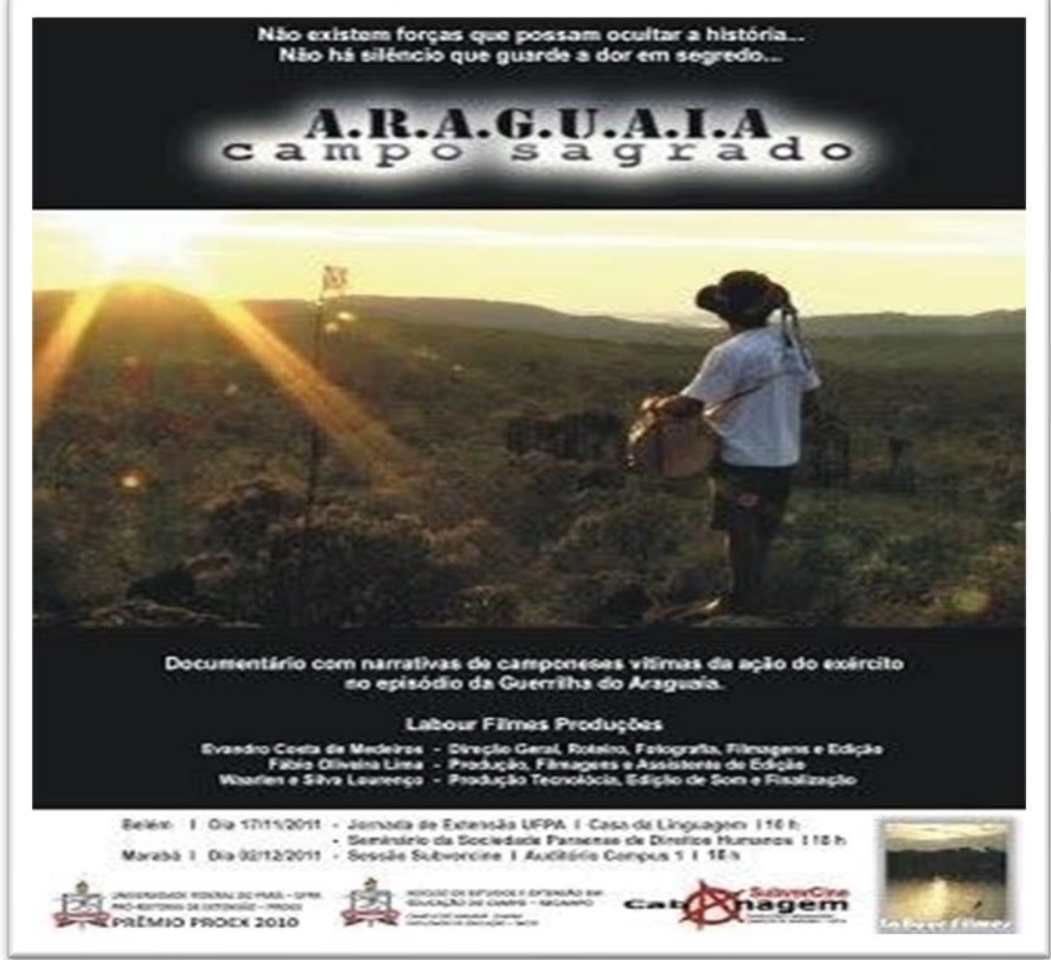

Fonte: (ARAGUAIA..., 2012).

\footnotetext{
${ }^{3}$ Documentário lançado em 2011 na cidade de Marabá, Estado do Pará, tendo a direção de Evandro Medeiros e produção de Labour Films, com duração de cinquenta minutos
} 
O documentário inicia com uma frase que é parte do livro Le Petit Prince, de 1943, do escritor francês Antoine de Saint-Exupéry, que anuncia “[...] que é preciso que eu suporte duas ou três larvas se quiser conhecer as borboletas", aparentemente um prenúncio das agruras que serão retratadas pelos sujeitos sociais. Na sequência, faz alusão à Serra das Andorinhas/Martírios localizada no município de São Geraldo-PA., local onde foram despejados os corpos dos guerrilheiros mortos pelos militares, demonstrando por fotos o poderio bélico e tático das forças armadas naquela época.

Ao mostrar o poderio militar no documentário, refletido no quantitativo de militares, em todo o aparato bélico e na forma como os militares se organizaram para o embate, são imagens utilizadas como símbolos que retratam a representação histórica da época, para assim, confirmar e agregar às falas dos atores sociais. Observa-se que a interpretação histórica, a partir da hermenêutica, não se pode inferir apenas "em seu correlato no conceito de expressão", mas atingir também o sentido oculto, aquilo que necessita de ser revelado para a construção histórica (GADAMER, 1999).

Faz como último ato de introdução da película, a citação de uma frase de autoria desconhecida que é "Não existem forças que possam ocultar a história [...]" que retrata a tentativa de demonstrar o que de fato ocorreu naquele período ditatorial. Após, segue-se uma visão de uma mata, onde alguém não identificado, devido ao fato de que a câmera ocupa o lugar do ator, caminha acelerado por uma trilha pela mata, de forma ofegante, provavelmente retratando um guerrilheiro ou camponês fugindo dos militares, momento em que, aos 3'01", se inicia a fala de um dos atores sociais, "Seu Beca", camponês da região.

Foi uma guerra suja, uma guerra massacrada. Em todo canto do corpo eu peguei choque. Passei quarenta e cinco dias preso, é... Trinta dia o 'armoço', a janta e o quebra jejum era 'pêa'; só o que a gente comia, dava de comer, mas quem que podia comer? Numa infelicidade dessa. Fui torturado, fui massacrado e fui judiado. Eu não dormi nem um pingo, nem um pingo, nem um pingo; orando a Deus a noite todinha, a lua bonita. A lua bonita, aí eu ... Eu orei a Deus, fiz um voto com o divino espírito santo pra não deixar fazer uma coisa daquela comigo. 


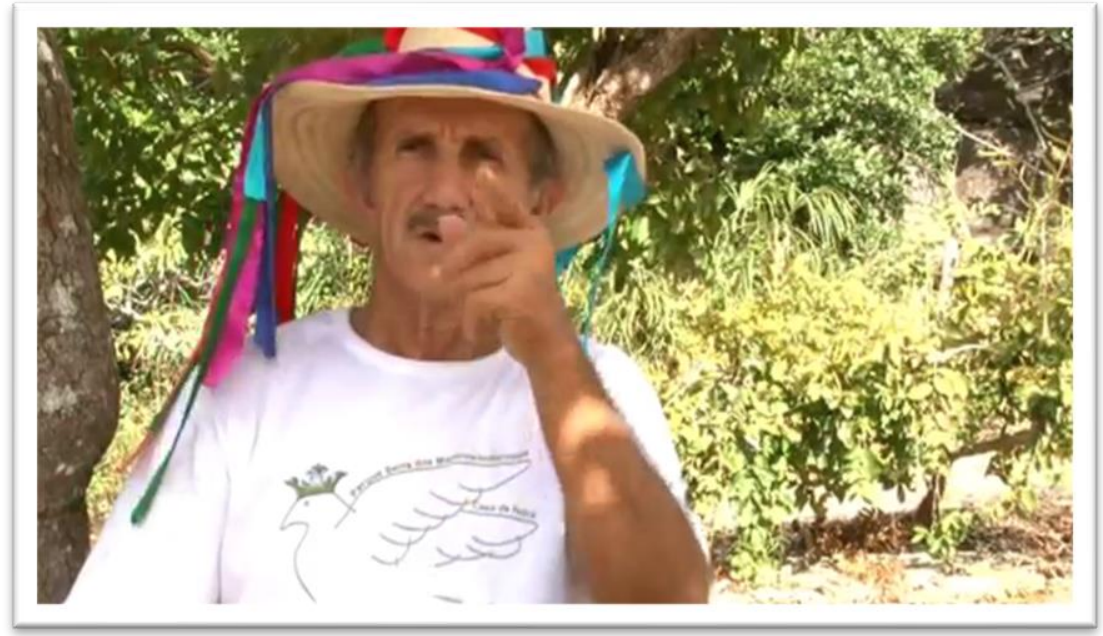

Fonte: (ARAGUAIA..., 2012).

Percebe-se no gestual do "Seu Beca", com os dedos em riste nas primeiras frases, que ele possui segurança naquilo que fala. Alega que sofreu tortura dos militares, que o deixaram sem comida, unicamente recebendo agressões nos horários das refeições. Percebe-se que se trata de uma pessoa religiosa, que clamou a Deus quando viu a lua, provavelmente, do local do cárcere, almejando a liberdade. No processo de intelecção das falas dos sujeitos sociais é primordial o afastamento de determinados preconceitos pois eles prejudicam a construção do saber do passado histórico, devendo se buscar de forma despida de autocompreensão o sentido então produzido (GADAMER, 2002).

Após a anunciação do título do documentário, ao som de tambores, e da bandeira contendo os dizeres litúrgicos Santíssima Trindade, com a apresentação do título do documentário, “Seu Beca” continua sua história. Com precisão de data, aos 03'15”, ressalta o dia do mês em que ocorreu sua prisão, e que foi conduzido à cidade de Xambioá-TO por militares que utilizaram um helicóptero para a sua locomoção. De forma bem simplória aduz que os militares queriam que sua esposa grávida, em dias de parto, o acompanhasse.

É... Dia 14 de Outubro de 1973, eu fui preso pelo exército brasileiro na região aqui do OP2. Eu "tava" com minha mulher gestante, pra ganhar criança em São Geraldo do Araguaia e tinha minha roça aqui, chamava Cento. Eu na região, na... No momento que ela tava no dia de ganhar nenê eu tinha mandado fazer uma farinha antes, tinha mandado fazer uma farinha, trinta saco de farinha. Tinha uma mandioca aqui na roça, mandei fazer uma farinha e ai o pessoal tava fazendo a farinha; dois, era dois homem e uma mulher. Ai eu... A mulher... Eu tinha mandado fazer a farinha e vim, é... Pegar a farinha, a mulher ficou assim com a cara meia ruim já, e eu digo: mulher se você vê que vai ganhar antes de eu chegar... "Não, tu vai de pressa e vem". Que era viagem de eu ir num dia e voltar no outro né. (...) Quando foi no dia 14 de tardezinha, baixou um "helicopi", nesse tempo eu num conhecia nem o que diabo era "helicopi". Era um "helicopi" pequeno, baixou lá onde é o INCRA hoje e era um campo de bola. Quando ela tava, é... Com a dor pra ganhar menino, eles entraram dentro do quarto e queria que a mulher ... O menino já no nascedor, ele queria que a mulher levantasse e 
caminhasse cinquenta quilômetros atrás de mim de pé. É... Ai... Voltaram, o povo pedindo... As mulher pedindo pra não fazer aquilo, ai a mulher chorando. Na hora que a mulher descansou, num tinha acabado nem de despachar, eles chegaram e pra mulher levantar do jeito que tivesse era pra levantar pra ir atrás de mim, aquela humilhação esquisita.

Ao relembrar a data com precisão, oferece a dimensão do tempo, que para a história é fundamental, pois é produto de sua expressão. "Matéria fundamental da história é o tempo; portanto, não é de hoje que a cronologia desempenha um papel essencial como fio condutor e ciência auxiliar da história" (LE GOFF, 2011).

Aos 04'5'2" de filme, no intervalo de fala de "Seu Beca", aparece uma cena em preto e branco de um helicóptero levantando voo por entre as serras; muito embora já na década de 60 , havia uma hegemonia do cinema em cores, o monocromático serve para fornecer sentido, aguçar a relação com a realidade, pois sem a distração das cores consegue-se a essência do sentido das coisas.

Podemos observar a presença da cor na narrativa no cinema, ao longo de sua história, como resultado não só do desenvolvimento tecnológico, mas como produto das relações combinatórias entre os elementos na produção de sentido, mesmo quando temos como referência a película monocromática combinada com as em cores, intencionalmente usadas para produzir sentido e significar (PALMER, 2015).

Ao ser conduzido na aeronave, os militares utilizaram de manobras que "Seu Beca" retrata como sendo "cavalo-de-pau", para que, ao sentir dele, ficasse atordoado. Percebe-se que, provavelmente, tais manobras serviam para assustá-lo, na tentativa de facilitar a condução de um possível interrogatório. Alega, também, que foi preso na condição de terrorista/guerrilheiro, em um trecho de seu depoimento relata que foi chamado de "bandido sabido", forma jocosa para retratar a resistência com que "Seu Beca" havia demonstrado nas perigosas manobras empreendidas pelos militares. Na parte final de sua fala, relata que haviam o levado para um local onde aparentava ser um curral, cercado de arame, no local já se encontravam outros presos, havendo uma proibição de proposições de conversas entre eles.

Na fala de "Seu Beca", tem-se a percepção que realmente há uma ação seletiva da memória ao aduzir sobre as ações dos agentes do Estado, aquela seletividade retratada por Le Goff (2011), onde vigora a particular dialética entre esquecimento e lembrança, onde a memória não se opõe ao esquecimento, mas se ajustam.

A partir desde momento, seguem as falas de outros atores sociais. Percebe-se que tal situação tem como escopo dar mais credibilidade aos fatos ali narrados, pois há uma sucessão

\footnotetext{
${ }^{4}$ Termo regional utilizado para demostrar manobras de risco e/ou perigosas.
} 
de falas que se encaixam enquanto produção de sentidos, as falas retratam as formas com as quais os militares chegaram na comunidade local.

Vale novamente destacar que os camponeses passaram anos embrenhados em silêncios, e também de alusões e metáforas, moldados pela "angústia de não encontrar uma escuta, de ser punido por aquilo que se diz, ou, ao menos, de se expor a mal-entendidos" (POLLACK, 1989), no entanto, se lembram de detalhes daquela época, isso se explica devido a intensidade da experiência.

“Dona Madalena”, camponesa, filha de torturado, aos 08'34", alega que havia a predisposição dos camponeses em dar acolhida aos guerrilheiros, pois chegavam na comunidade pedindo comida e o natural seria auxiliá-los. Porém, não sabiam das consequências do ato, o que fez com que vários camponeses fossem presos e torturados devido à ajuda fornecida. Quando a entrevistada "Dona Madalena", citando a acolhida aos guerrilheiros, exemplifica ao entrevistador que se este chegasse pedindo comida, ou no dizer da entrevistada "pedindo boia", seria de costume que ela fornecesse, demonstra o assentimento com a conduta dos demais camponeses, bem como retrata a fiel cultura camponesa, de partilha de alimentos.

$\mathrm{O}$ que as pessoas iam fazer? Eles chegavam na casa e um dava comida pra eles comerem. Quando eles descobria, né? Pegava a gente. A gente não sabia né? Porque, assim, por acaso você ta chegando hoje em minha casa e você tá com fome né?! Pede um prato de boia, claro que lhe dou, né?!. E era assim que acontecia aqui na região.

“Seu Joaquim”, aos 09’33”, pessoa já idosa, também relata o sofrimento da época, ao apontar para um conhecido ao seu lado em busca de confirmação, descreve as truculências dos militares, recordando de um camponês de alcunha de "Zé Novato" que foi preso em XambioáTO, deixado no buraco por um longo período e teve como sequela a paralisia.

O sofrimento aqui foi triste, aí teve deles aí que ficou paralitico como esse aqui que sabe disso, dessa história. Que o Zé Novato mesmo, coitado do véi Novato, foi preso nesse Xambioá bem aí, apanhou que ficou paralitico; passou não sei quantos tempos dentro de buraco de pedra e dentro de buraco no chão. 
Figura 03 - "Seu Joaquim” Camponês

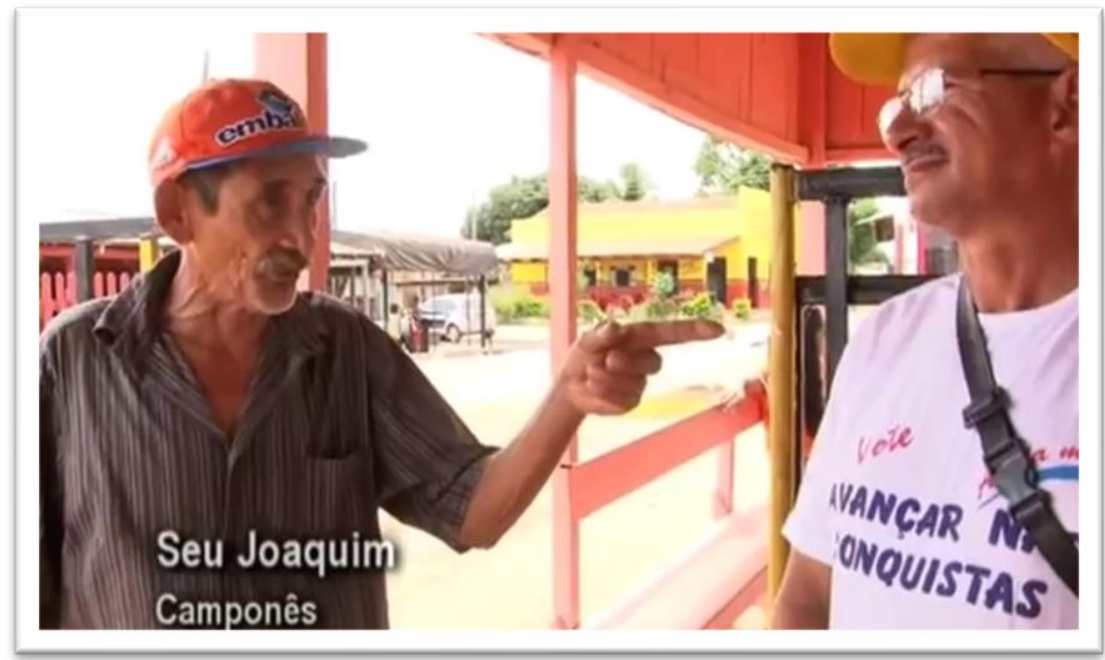

Fonte: (ARAGUAIA..., 2012).

$\mathrm{Na}$ imagem, "Seu Joaquim", dentro de alpendre no vilarejo, vestido de forma bem simplória, gesticulando e com firmeza em suas ponderações, relata os fatos ocorridos durante a guerrilha do Araguaia.

A partir 09'49” da película, os sujeitos sociais já entrevistados reaparecem dando prosseguimento às narrativas dos sofrimentos vivenciados na guerrilha, reafirmando os dizeres de outros entrevistados e trazendo novos fatos da época, de como os camponeses auxiliaram os guerrilheiros e como foi a atuação dos militares na região. Percebe-se nitidamente que o produtor da película faz os recortes para dar maior credibilidade às narrativas dos sujeitos sociais e ao seu próprio ponto de vista. Esta construção da representação da verdade, de um aspecto comum na narrativa, vem das intersubjetividades, assim identificada por Gadamer (2002), como comunhão de opiniões.

“Dona Madalena”, aos 09'52”, na continuidade de entrevista, retrata que as pessoas que foram detidas pelos militares na guerrilha sofreram com a violência, causando-lhes um mal irreparável, em suas palavras alega que "nunca mais foi homem, prestaram...[sic]". Ela recorda que um conhecido chamado "Silvano" chegou a vomitar sangue, devido aos maus-tratos. 
Figura 04 - "Dona Madalena" - Camponesa

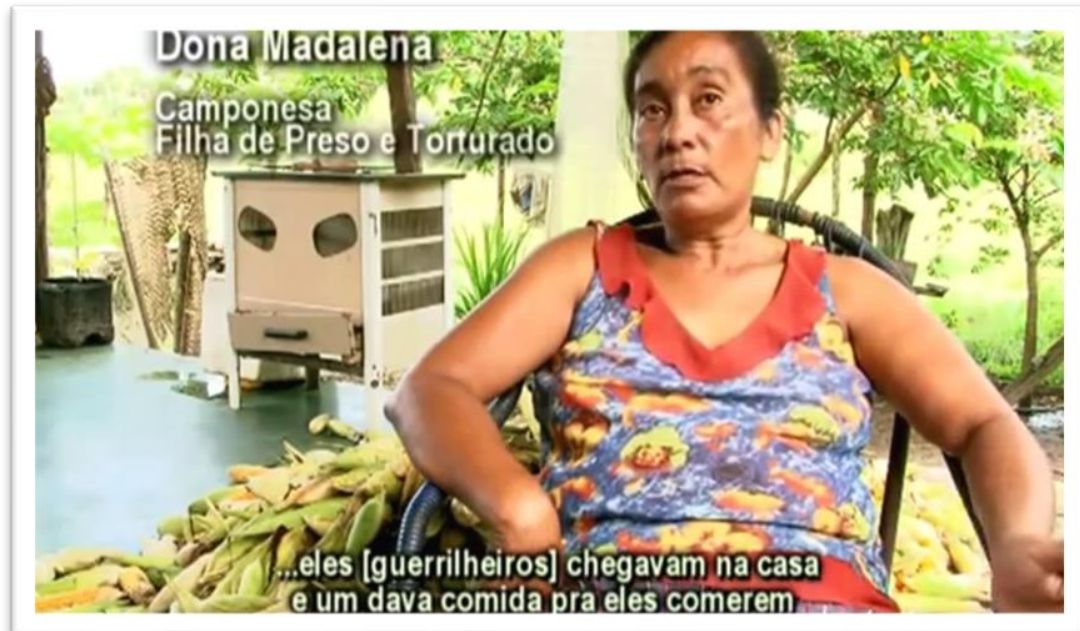

Fonte: (ARAGUAIA..., 2012).

A imagem acima demonstra um ambiente de vivência campesina, onde se tem ao fundo, espigas de milho para debulhar, bem como um fogão à brasa. Nota-se, então, que o idealizador da película priorizou um ambiente familiar ao entrevistado, para dar maior comodidade e naturalidade para o ato da entrevista.

O barqueiro Joaquim Borges, com o semblante ainda entristecido, diz que muitos ainda estão doentes devido à violência praticada pelos militares naquela época; em um sinal de dor ao relembrar o passado, abaixa a cabeça, surgindo então a técnica cinematográfica denominada fade-out, que se trata do escurecimento gradativo da imagem, servindo, neste caso, aparentemente, para dar mais consternação à cena.

Aos 16’20” do documentário, com imagens da Vila Boa Vista, em São Geraldo do Pará, os camponeses João de Deus e "Seu Messias" relatam que os guerrilheiros auxiliavam com tratamento de saúde independentemente de possuírem recursos. Próximo dali, demonstram onde seria o local de alojamento dos guerrilheiros, em uma fazenda às margens do Igarapé dos Caianos. Os camponeses começam a indicar onde seriam a casa e o local de banho dos guerrilheiros.

Destaca-se que as diversas cenas que demonstram lugares e coisas que indicam o episódio da guerrilha do Araguaia, são utilizadas pelo produtor para fazer o efeito de aguçar as lembranças deste fato histórico e suas nefastas consequências.

Ainda que seja tecnicamente difícil ou impossível captar todas essas lembranças em objetos de memória confeccionados hoje, o filme é o melhor suporte para fazê-lo: donde seu papel crescente na formação e reorganização e, portanto, no enquadramento da memória. Ele se dirige não apenas às capacidades cognitivas, mas capta as emoções (POLLACK, 1989). 
Como visto, o filme, por suas peculiaridades e abrangência, se torna um excelente suporte para a veiculação dos objetos de memória, na produção de reminiscências na representação da verdade.

Nas entrevistas realizadas para o documentário, denota que das lembranças advindas do processo de rememorização realizado pelos atores sociais, afloram as emoções calcadas no sofrimento, sentimento de revolta e vontade de justiça.

"Seu Joaquim” alega também que não sabia o significado da expressão, mas com a inocência no olhar, diz que mesmo nos dias de hoje, não sabe o significado pois nunca esteve no exterior. "Seu Joaquim" transparece em sua fala e gestos com os braços, expressando o desconhecimento, uma certa preocupação com o real significado do termo terrorista, aparentemente supondo estar equivocado em seus dizeres. Diz o seguinte: "Uma coisa que eu nem sei o que diabo é terrorista, eu pelo menos não sabia, e nem sei, porque eu nunca fui pro exterior e dentro do nosso Brasil não existe isso. Se existiu é de poucos tempos pra cá".

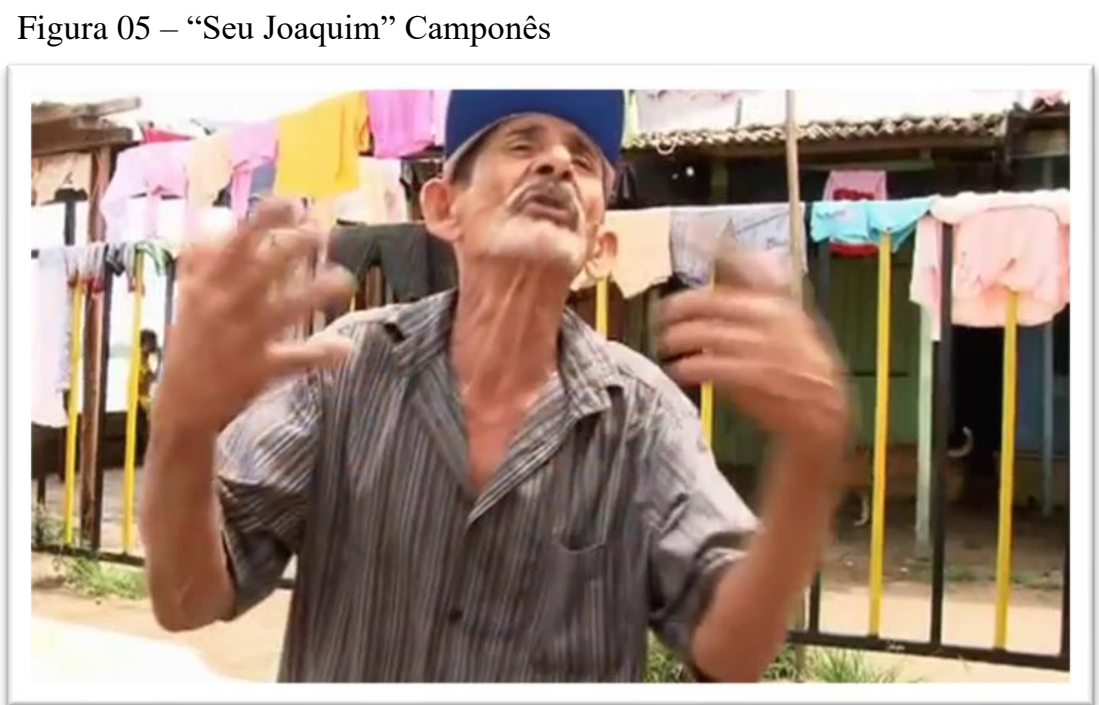

Fonte: (ARAGUAIA..., 2012).

Prossegue o documentário com a continuação do depoimento de "Seu Beca", aos 19'15”, que vem aduzir que os guerrilheiros não eram terroristas, seriam um povo sofredor, pois o que eles queriam era um país menos "cativo", com mais liberdade, alega que os guerrilheiros o convidaram a se unir na mata, mas com receio dos militares não houve o aceite ao convite. Nesta parte, "Seu Beca" diz que se os camponeses tivessem consentido em aderir aos anseios dos guerrilheiros, já estariam todos mortos. O que se pode inferir é que o 
entrevistado ao vivenciar a atuação dos militares, deve ter percebido o poderio bélico e tático, bem como a quantidade bem superior de militares frente aos guerrilheiros.

Na continuação do documentário, aos 20’46”, aparece mais uma frase destacada em um fundo na cor preta, com os dizeres "não há corpo que não sangre suas memórias..." mais uma frase de autoria não informada, que traz o prenúncio do local onde foram depositados os corpos dos guerrilheiros mortos violentamente.

“Dona Marcolina”, aos 26’27”, recorda-se quando seu companheiro foi retirado pelos militares da própria casa, detalhando que estava na fonte no momento, chegando em casa indagou sobre o paradeiro de José, seu companheiro, onde ficou sabendo da notícia de que os militares haviam o levado, não tendo mais contato com o companheiro. Relata que chegavam notícias de que ele havia ficado com distúrbios mentais, suscitando que provavelmente devido à violência empreendida pelos militares. Mais uma narrativa bem detalhada que demonstra a latência do sentimento de impotência frente ao ocorrido na guerrilha. Durante a fala da entrevistada, mostra-se imagens dela se deslocando ao quadro fotográfico da família colocado na sala de sua casa, com a presença de algumas crianças, a cena provavelmente é passada para fornecer uma maior dimensão da dor de "Dona Marcolina".

Figura 06 - "Dona Marcolina" verificando a posição do quadro da família

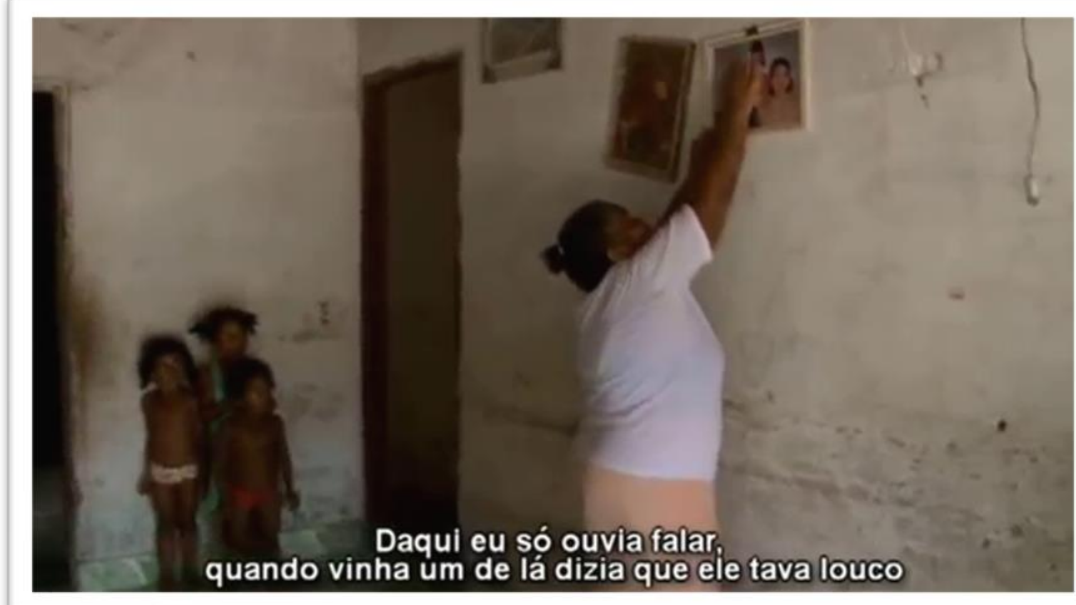

Fonte: (ARAGUAIA..., 2012).

Aos 29'27" do documentário, aparece a frase "Não há mortos que perdoem o braço forte e mão amiga de seus carrascos e assassinos", frase de autoria desconhecida, que traz dentro dela o slogan do Exército, no intuito de fazer alusão ao próximo contexto que se refere 
à violência e crueldade com que os militares conduziam a ação na mata, utilizando dos camponeses, que eram os mateiros, guias daquela época.

Aos 41'11" da película, passa-se a continuidade da entrevista do mateiro Sinézio, que aparentemente irritado com o questionamento do entrevistador, chegando a mencionar que se ele soubesse o que era guerra não perguntava aquilo para ele, diz que estava com muito medo, mas tinha que obedecer ao comando dos militares. Breve pausa de imagem, novamente Sinézio, que consternado, diz que guerra é guerra, passível de morte de qualquer um. Neste instante utiliza-se o fade-out e em seguida o fade-in, o escurecimento e o reaparecimento da imagem, neste momento, sem verbalizar, Sinézio aparenta se encontrar incomodado com a gravação, pelo fato de estar muito entristecido com o ato de relembrar o passado.

Meu patrão, se uma pessoa se achar, qualquer um homem se achar no meio do exército do jeito de guerra, você também não sabe o que é guerra?! sabe não... sabe não... Se o senhor soubesse não dizia uma coisa dessa pra mim. Que eu tava ansioso, eu tava era cagando de medo, mas o que eu ia fazer no meio de uns homens desses? Tem jeito não meu filho, guerra é guerra! Morre quem merece, quem não merece, morra criança, morra mulher, morra todo mundo! Essas mulheres tudo sofreram com os maridos apanhando.

Figura 07 - Momento em que Sinézio aparenta um excessivo constrangimento

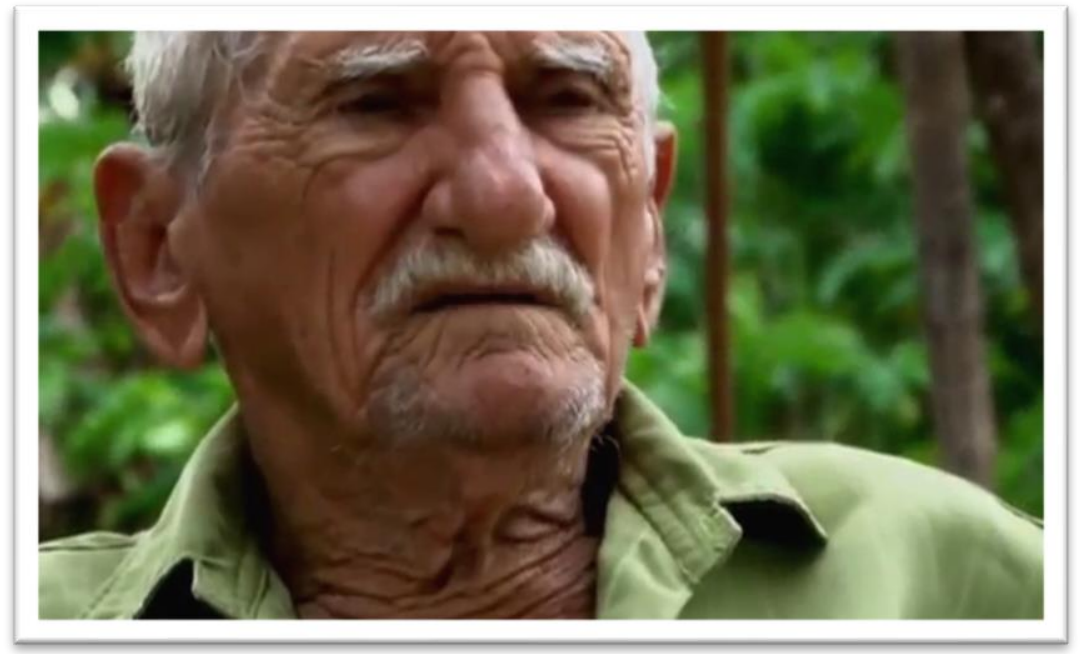

Fonte: (ARAGUAIA..., 2012).

Aparece no documentário, aos 46'25”, os caracteres com os dizeres "para não calar o divino festeja a vida [...]" anunciando a manifestação religiosa, cultural e tradicional realizada pelos romeiros no Festejo do Divino Espírito Santo. É apresentada a cena do Parque Estadual da Serra das Andorinhas, em São Geraldo do Araguaia-PA., local por onde passa a romaria. Este movimento de lembrança e esquecimento faz aguçar a memória da dor no momento da 
celebração. Ressalta-se, também, que "a vontade de esquecer os traumatismos do passado frequentemente surge em resposta à comemoração de acontecimentos dilaceradores" (POLLAK, 1989).

"Seu Beca" em sua última fala no documentário, alerta que "sem a fé nós não somos ninguém", demonstrando uma devoção ao litúrgico. Diz que participa desde o início da romaria, sempre auxiliando os romeiros na subida da serra.

\begin{abstract}
Nós sem a fé, nós não somos ninguém. Foi o tempo que começou esse festejo aqui, o padre foi quem mandou me chamar, o padre Nonato, pra formar esse festejo aqui na Serra das Andorinhas. Que eu tinha um burro pra carregar os trem do romeiro pra cá. Ai comecemos, e ai eu fiquei naquela luta, carregando gente todos os anos, todos os anos, todos os anos. Todos os anos carregando gente, quando eu "guentei" dezessete anos eu carreguei romeiro sem cobrar nada. Tinha dia de eu não... Eu só assistia só de noite, de dia eu não assistia. Chegava aqui, nesse tempo tinha uma saúde... Tinha cinco burro bom. Ai, a multidão de gente foi aumentando, aumentando e então, é, tem sido a Romaria, tem sido pra quem tem fé, tem feito promessa que é válida aqui, graças a Deus e tamos juntos nessa luta.
\end{abstract}

Com o canto típico da Romaria, aparece a imagem da Casa da Pedra, Santuário do Divino na serra das Andorinhas, bem como as práticas litúrgicas realizadas pela romaria. Podese perceber que a narrativa religiosa serve para demonstrar que mesmo diante de um passado tenebroso, onde foram deixadas marcas indeléveis, ainda assim, emerge a esperança de um povo, consciente de sua força, onde de vitimados passam a ser protagonistas de um futuro melhor, com liberdade e justiça.

Figura 08 - Festejo do Divino

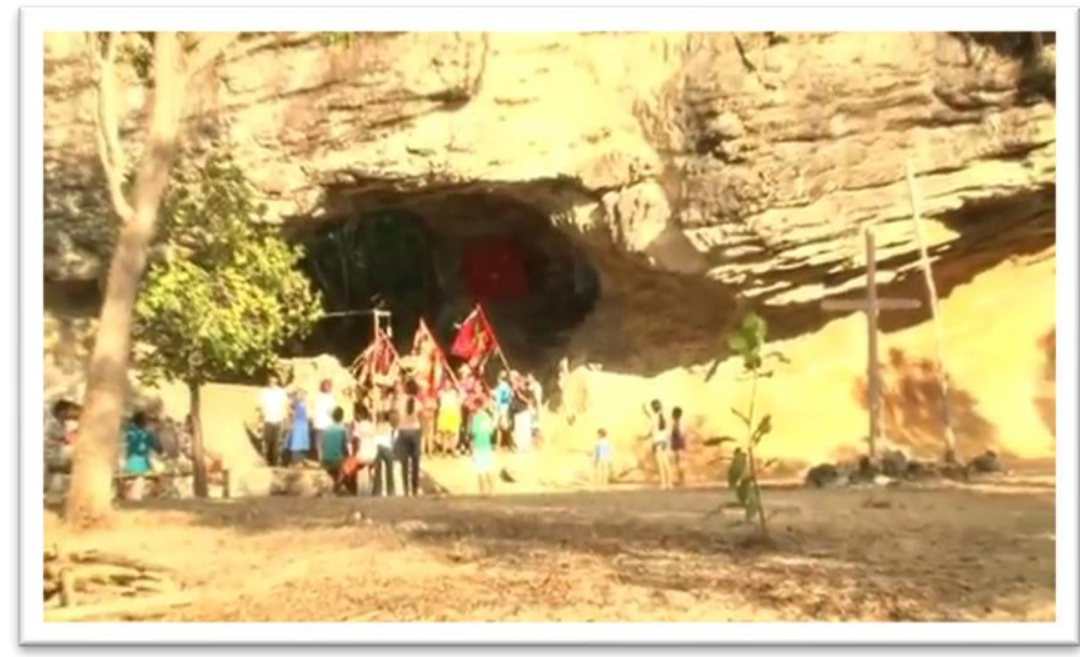

Fonte: (ARAGUAIA..., 2012). 
$\mathrm{Na}$ parte final do documentário, aparece a frase "Não há forças que possam deter a história que emerge da dignidade humana [...]", a expressão serve para demonstrar que mesmo com toda força exercida para ocultar a verdade, ela sobressai na própria essência humana; e, apontar a situação degradante vivenciada na época da guerrilha, contextualizada em toda a produção fílmica, é uma forma de comunicação para propalar uma representação da verdade, na produção de pensamentos não dissentidos.

\begin{abstract}
É somente pela capacidade de se comunicar que unicamente os homens podem pensar o comum, isto é, conceitos comuns e sobretudo aqueles conceitos comuns, pelos quais se torna possível a convivência humana sem assassinatos e homicídios, na forma de uma vida social, de uma constituição política, de uma convivência social articulada na divisão do trabalho. Isso tudo está contido no simples enunciado: o homem é um ser vivo dotado de linguagem (GADAMER, 2002).
\end{abstract}

A comunicação através da linguagem ganha extremo relevo quando se pretende, através de uma memória coletiva, alçar a representação da verdade de um fato histórico. Devido à comunicação entre os agentes sociais se tem um vislumbre de uma linha de raciocínio que se perpetua na produção das reminiscências.

O Documentário finaliza com a música de Zé Ramalho, “As danças das borboletas” e a imagem de um pôr do sol, seguindo-se os créditos da película. A invasão das borboletas é propícia para indicar, no contexto do documentário, a disseminação da verdade aos olhos daqueles que foram esquecidos pela história. Os camponeses, atores sociais na produção fílmica "Araguaia: Campo Sagrado", trazem à lembrança os movimentos ocorridos durante a ditadura militar, precisamente na guerrilha do Araguaia, que mudaram a vida e o cotidiano daqueles que sobreviveram ao regime de exceção.

No momento em que se finaliza o documentário, tem-se a percepção que a memória coletiva produzida pelos sujeitos sociais é arraigada de detalhes da atuação dos agentes do estado dentro da região daquela comunidade. Permanecendo viva a memória das relações interpessoais com os guerrilheiros, percebe-se que os atores sociais cultivaram bastante apreço por aqueles que eram contrários ao regime militar e, em sua maioria, se identificaram com a causa; bem como se tem perceptível que as investidas dos agentes do Estado às margens do Rio Araguaia, principalmente com o povo ribeirinho, foram avassaladoras, subjugando o campesinato e aproveitando de sua simplicidade.

\title{
Considerações finais
}


Nas seções do presente trabalho acadêmico abordou-se a partir do documentário “Araguaia - Campo Sagrado", a produção da memória da guerrilha do Araguaia, ocorrida no ano de 1971, centrada nas falas dos sujeitos sociais presentes naquela produção fílmica.

Ao se dedicar ao processo de decupagem do objeto de pesquisa, cuidou-se de abordar a construção fílmica desde suas primeiras cenas, demonstrando a forte predominância do produtor em retratar em imagens as atrocidades do regime militar e da atuação das forças armadas na guerrilha do Araguaia.

Nas falas dos entrevistados, em sua maioria camponeses, por muito tempo silenciados, percebeu-se que além dos guerrilheiros, o campesinato da região também foi atingido naquele embate, as comunidades ribeirinhas amargaram as crueldades advindas da guerrilha. Os atores sociais presentes no documentário demonstram uma coerência em suas falas, aparentemente o produtor fez durante a técnica da montagem das cenas, uma coordenação nas aparições dos sujeitos, demonstrando uma harmonia na produção de sentidos.

Emerge das falas dos sujeitos sociais, sobretudo camponeses, o pavor vivenciado na época e, dentre eles, alguns que com receio e medo, tiveram que auxiliar os militares em meio às matas, sacrificando a vida de outros camponeses. Houve uma série de atos atrozes por parte dos militares para amedronta-los e forja-los a não auxiliar os guerrilheiros, bem como dizer sobre a localização destes.

Ao longo do estudo, denota-se que por muito tempo, os camponeses e índios permaneceram silenciados pela ausência de suas versões junto a história dita oficial. A representação da verdade vista aos olhos destes camponeses é um fato cuja crueldade do regime é novamente reafirmada.

\section{Referências}

ARAGUAIA: Campo Sagrado. Direção: Evandro Medeiros. Produção: Labour Filmes. Direção: Evandro Medeiros. Roteiro: Paulo Fonteles Filho. (53min.). Disponível em: <https://www.youtube.com/watch?v=e44hXBBaHrw>. Acesso em: 3 fev. 2017.

BERNADET, Jean-Claude. O que é cinema. São Paulo: Brasiliense, 2012.

GADAMER, Hans-Georg. O problema da consciência histórica. Rio de Janeiro: FGV, 1999.

Verdade e método: traços fundamentais de uma hermenêutica filosófica. 4. ed. Petrópolis: Vozes, 2002. 
LE GOFF, Jacques. História e memória. São Paulo: Editora da Unicamp, 2011.

MEDEIROS, Euclides Antunes de. Guerrilha do Araguaia: memórias à margem da história. Outros Tempos, v. 10, n. 16, p. 256-284, 2013.

NICHOLS, Bill. Introdução ao documentário. Campinas (SP): Papirus Editora, 2005.

PALMER, Marcos Ubaldo. Cor e significação no cinema: produção de sentido no filme A Invenção de Hugo Cabret, de Martin Scorsese, 2015. Disponível em: http://www.biblioteca.pucminas.br/teses/Comunicacao_PalmerUP_1.pdf. Acesso em: março 2018.

POLLAK, Michael. Memória, Esquecimento, Silêncio. Revista Estudos Históricos, Rio de Janeiro, v. 2, n. 3, 1989.

POLLAK, Michael. Memória e identidade social. Revista Estudos Históricos, Rio de Janeiro, v. 5, n. 10, 1992.

RICOEUR, Paul. A memória, a história, o esquecimento. Campinas (SP): Editora da Unicamp, 2007.

SANTOS, Hilário Xavier dos. O essencial da ditadura militar brasileira. São Paulo: Luminária Academia, 2014.

SILVA, L. H. O. Memórias da guerrilha: acontecimento e história. In: MENDES, Conrado Moreira; LARA, Gláucia Muniz Proença (org.). Em torno do acontecimento: uma homenagem a Claude Zilberberg. Curitiba: Appris, 2016, p. 141-162.

SOUZA, Tania Conceição Clemente de. A análise do não verbal e os usos da imagem nos meios de comunicação. RUA - Revista do Núcleo de Desenvolvimento da Criatividade da Unicamp - NUDECRI, vol. 7 (65-94), Campinas, 2001. 